\title{
Identification of New Wheat Genes for Durable Resistance of Adult Plants to Yellow Rust (Puccinia striiformis Westend. f. sp. Ericks)
}

\author{
J.L. ZÁrate-Castrejón ${ }^{1}$, C.L. Aguirre-Mancilla ${ }^{1}$, E. Solís-Moya ${ }^{2}$, J.E. Ruiz-Nieto ${ }^{3}$, \\ J.C. RAYA-PÉReZ ${ }^{1}$, J.G. RAmíreZ-Pimentel ${ }^{1}$ and V. Montero-TaVera ${ }^{2 *}$ \\ ${ }^{1}$ Tecnológico Nacional de México, Instituto Tecnológico de Roque, Celaya, 38110, México \\ ${ }^{2}$ Instituto Nacional de Investigaciones Forestales, Agrícolas y Pecuarias, Celaya 38110, México \\ ${ }^{3}$ Universidad de Guanajuato, Campus Irapuato-Salamanca, Salamanca, 36500, México
}

(Received 30 April 2018; Accepted 17 June 2019;

Communicated by Á. Mesterházy)

\begin{abstract}
Yellow rust is a wheat disease caused by Puccinia striiformis, this pathogen causes economic losses in susceptible materials, which represent up to $70 \%$ of wheat varieties. Currently, the incorporation of genetic resistance through molecular tools, is a process used in the generation of new varieties resistant to this pathogen. A strategy employed to identify genes involved in the resistance to yellow rust is to screen differential EST obtained by suppressive subtractive hybridization. In this research, cDNA was extracted from healthy and inoculated plants from the resistant line V-26 from INIFAP. A set of 200 differentially expressed EST were cloned and sequenced, and 31 of them were selected for expression profile analysis by RT-PCR; additionally, with the aim of validate RT-PCR results, five genes were selected for RT-qPCR analysis in genotypes inoculated by $P$. striiformis. The results showed high levels of expression of selected genes in genotypes classified as resistant in the field conditions $(21,143,230,242,261$ and 277), while in the susceptible genotype 16, few genes were induced by the rust. Expression profiles confirmed significant differences between resistant and susceptible lines.
\end{abstract}

Keywords: subtractive suppressive library, minor genes, expression profiles, RT-PCR, RT-qPCR

\section{Introduction}

Yellow rust is a disease of wheat caused by the Basidiomycete fungus Puccinia striiformis Westend f. sp. tritici Ericks, which causes significant worldwide economic losses (Rodríguez-García et al. 2009; Ali et al. 2014). Currently, different strategies are used to control rust; for example, agronomic practices decrease the incidence of the pathogen by using wheat varieties with specific resistance to yellow rust (Huang et al. 2013), by biological control with Bacillus subtilis (Reiss and Jørgensen 2017), and by fungicide applications (Jørgensen et al. 2014; Mishra et al. 2015). However, the pathogens have developed resistance to these practices via the evolution and emergence of new races. For

*Corresponding author; E-mail: montero.victor@inifap.gob.mx 
this reason, growers have been obligated to increase the frequency of pesticide applications; however, these practices increase the production cost, induce soil pollution and kill beneficial species (Hussain et al. 2014; Huang et al. 2013). The use of genetic resistance is the best form of control since it is durable, environmentally friendly and cost-effective. It is imperative to search for new sources of durable and non-specific resistance genes (Huang et al. 2013; Solís-Moya et al. 2014).

Genetic studies have suggested that resistance to yellow rust is due to the presence of minor effect genes expressed in the adult plant stage. Individually, the effect of each of these genes is insufficient to confer resistance against the pathogen; however, together they are capable of increasing durable resistance (Huang et al. 2013). This response is not hypersensitive and probably operate only in the adult plant stage. This mechanism is very important because it is difficult for the pathogen to overcome plant resistance caused by the expression of several genes of minor effect. Since 1980 it has been shown that the cultivars Gaines, Nugaines and Luke are among the best examples of durable, adult plant, race-non specific resistance (Milus and Line 1986); indeed Lagudah (2011) mentions that there are few genes related to APR in wheat and a considerable proportion are non-specific race resistance, although a limited number are race specific. On the other hand, in the field, different severity levels caused by rust have been observed, and this phenomenon is regulated by the function of minor effect genes. In this sense, the research of Yang et al. (2011) demonstrated that the combination of major effect genes with minor effect genes increases the durability of the resistance to yellow rust; however, the mechanisms of resistance that were implicated are still unknown. It is possible that some of these genes are associated in a QTL and consequently cosegregate, however if a gene is not expressed it will not have any effect on the resistance, for that reason it is very important to carry out studies about the expression of the genes and how fine regulation is performed to determine if they have a role in the resistance of the adult or seedling plant and the exact phenological stage and conditions in which it is expressed.

One strategy to find yellow rust resistance genes is to screen differentially expressed sequence tags (EST) through the construction of a suppressive subtractive library. To understand the plant-fungal interactions, molecular processes from the pathogen in the first hours post-infection have been studied; these studies have considered the performance of cDNA libraries of Puccinia striiformis at three developmental stages: i) in the first hours post-inoculation, ii) in the first stages of development, and iii) in the establishment of the biotrophy by parasitic fungi; (Yin et al. 2009; Ma et al. 2009). The aim of this study was to isolate and identify genes of minor effects involved in the durable resistance to yellow rust (P. striiformis) of wheat in the adult plant stage at field conditions.

\section{Materials and Methods}

\section{Biological materials}

For the subtraction of genes related to the resistance to yellow rust, foliar tissue (flag leaf) from a rust-resistant advanced line (V-26) from the National Wheat Programme of Insti- 
tuto Nacional de Investigaciones Forestales, Agrícolas y Pecuarias (INIFAP) was used. To ensure the presence of rust in the field, a highly susceptible variety (Morocco) was inoculated with a mixture of the rust races CMEX14.25 and MEX14.141 of P. striiformis. The inoculation was performed through a spore suspension $\left(225,000 \mu \mathrm{L}^{-1}\right)$, which was hydrated in water treated with Tween 20 . The solution was injected into the base of the stem. Morocco was planted on the edges and corridors of the plots with the purpose to be a disperser of the rust, and then tissue samples of all wheat lines were taken when Morocco was $100 \%$ damaged by the fungus; on the other hand, yellow rust-free wheat was sown; the cultivation was performed during the 2014 fall-winter cycle. For expression profiles, 22 advanced lines were obtained from the Valle de México Experimental Field of INIFAP (Table 1); these materials were exposed to yellow rust in the 2015 springsummer cycle.

Table 1. Pedigree and incidence of yellow rust of genotypes used for gene expression profiles and RT-qPCR

\begin{tabular}{|c|l|c|}
\hline \multicolumn{1}{|c|}{ Pedigree } & Severity of rust (\%) \\
\hline 275 & Diamante/Josecha a & 5 \\
\hline 59 & Josechaf2007/3/Darwar dry//Seri/Rayón & 10 \\
\hline 96 & Diamante/Urbina & 10 \\
\hline 133 & Diamante/Yeso & 10 \\
\hline 143 & Arseniato/Apatita & 10 \\
\hline 230 & Aprot10/ICA 30.05//Nana a & 10 \\
\hline 233 & Aprot10/ICA 30.05//Nana b & 10 \\
\hline 277 & Diamante/Josecha b & 10 \\
\hline 278 & Diamante/Josecha c & 10 \\
\hline 212 & Diamante/Silvinita//Celestina a & 20 \\
\hline 213 & Diamante/Silvinita//Celestina b & 20 \\
\hline 242 & Hierro/Colibrí//Colibrí & 20 \\
\hline 309 & Aprot21/Colibrí & 20 \\
\hline 21 & Gema C2004 & 30 \\
\hline 261 & TJB368/Buc//Cupe/3/Ene/Zita & 30 \\
\hline 265 & Hierro/Colibrí & 30 \\
\hline 2 & Urbina S2007 & 40 \\
\hline 55 & Grafito/ICA 30.05 & 60 \\
\hline 66 & Colibri/Tragopan & 40 \\
\hline 16 & Salamanca S75 & 60 \\
\hline 45 & Grulla/h-16-2-15/4/Site/Mo/3/Vorona/Bau//Bau & 10 \\
\hline 63 & Frailecillo/Bimbo 40 & 10 \\
\hline
\end{tabular}




\section{Suppressive subtractive library}

\section{Extraction of total RNA}

Samples of flag leaves from the V-26 line were collected and immediately frozen in liquid nitrogen and stored at $-70{ }^{\circ} \mathrm{C}$ until further treatment. The frozen tissue $(500 \mathrm{mg})$ was homogenized in a mortar to obtain a fine powder. Extraction of the total RNA was completed by the Zymo Research kit (ZR Plant RNA MiniPrep ${ }^{\mathrm{TM}}$, USA) following the manufacturer's protocol. RNA integrity was verified by electrophoresis under denaturing conditions on $1.5 \%(\mathrm{~m} / \mathrm{v})$ agarose gel, which were stained with GelRed® (Fremont, CA). Images were visualized with UV light in a Carestream Health Inc. Molecular Imaging System (Gel Logic 112, USA).

After extracting the total RNA from rust-infected and healthy plants, single strand cDNA was synthesized using the SuperScript $\mathrm{II}^{\mathrm{TM}}$ kit (California, USA). For double strand synthesis, the single strand of cDNA was used as the template and Advantage enzyme (Clontech, Palo Alto, USA) was used. The reaction consisted of $25 \mu \mathrm{L}$ of $10 \mathrm{X}$ Advantage buffer, $1 \mu \mathrm{L}$ of each $10 \mathrm{mM}$ dNTP, $1 \mu \mathrm{L}$ of $10 \mathrm{mM}$ 5'-PCR IIA primer, $1 \mu \mathrm{L}$ of $10 \mathrm{mM}$ CDS primer and $3 \mu \mathrm{L}$ of enzyme $\left(2.5 \mathrm{U}_{\mu} \mathrm{L}^{-1}\right)$. Once all double strand DNAc were synthesized, they were purified using the QIAquick kit (QIAGEN, Germany) according to the manufacturer's protocol.

Genes differentially expressed were subtracted using the commercial PCR-Select cDNA Subtraction ${ }^{\circledR}$ kit (Clontech), according to the manufacturer's instructions. Finally, fragments of EST were amplified by PCR and the products were visualized on agarose gels as previously described. The fragments were purified on the QIAquick commercial kit to ligate them to the vector pGEM-T Easy (Promega, Madison, USA).

\section{Sequencing of differentially expressed genes}

The subtracted genes were ligated to the cloning vector to transform competent $E$. coli DH-5 $\alpha$ cells (Invitrogen) by heat shock (Sambrook and Russell 2001); $50 \mu \mathrm{L}$ of these cells were cultivated by the diffusion method in LB medium supplemented with ampicillin $\left(100 \mu \mathrm{g} \mu \mathrm{L}^{-1}\right), 100 \mu \mathrm{L}$ of IPTG $(0.1 \mathrm{M})$ and $20 \mu \mathrm{L}$ of X-Gal $(50 \mathrm{mg})$ (Sigma, St. Louis, USA). Recombinant colonies were reproduced into liquid LB medium with ampicillin $(100 \mu \mathrm{g})$. The plasmidic DNA of each colony was obtained by alkaline lysis using the method of Bimboim and Doly (1979). The presence of the inserts was checked by PCR using the universal primers SP6 and T7. The reaction mixture consisted of $1 \mu \mathrm{L}$ of template (500 ng $\left.\mu \mathrm{L}^{-1}\right), 15.5 \mu \mathrm{L}$ of water, $2.5 \mu \mathrm{L}$ of buffer $(10 \mathrm{X}), 1 \mu \mathrm{L}$ of $\mathrm{MgCl}_{2} 50$ $\mathrm{mM}, 1 \mu \mathrm{L}$ of $10 \mathrm{mM}$ dNTPs, $1 \mu \mathrm{L}$ of each $10 \mathrm{mM}$ primer and $0.2 \mu \mathrm{L}$ of Taq polymerase enzyme $\left(5 \mathrm{U} \mu \mathrm{L}^{-1}\right)$. The amplification programme consisted of a denaturation at $95{ }^{\circ} \mathrm{C}$ for $5 \mathrm{~min}, 25$ cycles of $95^{\circ} \mathrm{C}$ for $1 \mathrm{~min}, 60^{\circ} \mathrm{C}$ for $2 \mathrm{~min}, 72^{\circ} \mathrm{C}$ for $2 \mathrm{~min}$ and an extension phase of $72{ }^{\circ} \mathrm{C}$ for $5 \mathrm{~min}$. Plasmids of the transformed bacteria were sequenced at the National Laboratory of Genomics for Biodiversity, CINVESTAV-Irapuato. The sequenced fragments were edited using the LaserGene ${ }^{\circledR}$ program (DNASTAR, 
Madison, USA) and aligned using the BLAST algorithm to find similarities with previously reported sequences. Primers for each EST were then designed with the PrimerBLAST tool.

\section{Gene expression}

RNA was extracted from 22 rust infected wheat genotypes from flag leaves. The tissue was frozen in liquid nitrogen and homogenized to obtain $500 \mathrm{ng}$ of fine powder; the RNA extraction was performed according to the method of Logemann et al. (1987). The single strand of cDNA was synthesized using the commercial SuperScript ${ }^{\mathrm{TM}}$ II Reverse Transcriptase kit. Prior to gene expression analysis, a bulk was made with all single-stranded cDNA samples to test pair primers designed on sequences of differentially expressed EST. 31 of 49 pair primers were selected (Table S1*); the selection criterion was the presence of a well-defined amplified fragment of expected size. For densitometry analysis the signal intensity of the $26 \mathrm{~S}$ gene was normalized with the aim of detecting differences in expression in the selected genes (Montero-Tavera et al. 2017). The PCR reactions were performed as previously using $2.5 \mu \mathrm{L}$ of $10 \mathrm{mM} 26 \mathrm{~S}$ primers. The amplification conditions and the visualization of products were as previously described. The gels were photographed and the densitometry analysis was performed with the Total Lab Quant TL120 v. 2008 software. Densitometry data were analysed to find differences in gene expression among wheat materials. The threshold for determining whether a gene was induced, repressed or constitutive was established based on the mean expression of the infected and uninfected susceptible materials.

\section{Validation of gene expression by RT-qPCR}

The purpose of this step was to validate the results obtained by RT-PCR. The samples considered for this analysis were lines 16, 21 and 143, which presented low, medium and high expression levels, respectively; the expression of the TaYr-1, TaYr-8, TaYr-10, TaYr32 and TaYr-49 genes was studied using the One Step Real-Time PCR System (Applied Biosystems). Preliminary standard curves were constructed from $400 \mathrm{ng} \mu \mathrm{L}^{-1}$ of cDNA in serial solutions $(1: 10)$ to determine the amplification efficiency for each pair of primers. Each reaction consisted of $12.5 \mu \mathrm{L}$ of $2 \mathrm{X}$ buffer, $1.5 \mu \mathrm{L}$ of $10 \mathrm{mM} 26 \mathrm{~S}$ primers, $10 \mu \mathrm{L}$ of water and $1 \mu \mathrm{L}$ of template at a concentration of $50 \mathrm{ng} \mu \mathrm{L}^{-1}$. Three replicates were performed for each concentration. The RT-qPCR conditions were $95^{\circ} \mathrm{C}$ for $10 \mathrm{~min}$, followed by 40 cycles of $15 \mathrm{~s}$ at $95{ }^{\circ} \mathrm{C}, 60^{\circ} \mathrm{C}$ for $30 \mathrm{~s}$ and $72{ }^{\circ} \mathrm{C}$ for $30 \mathrm{~s}$, and one extension cycle at $72{ }^{\circ} \mathrm{C}$ for $30 \mathrm{~s}$. The melting curve was measured from $60{ }^{\circ} \mathrm{C}$ and ended at $95^{\circ} \mathrm{C}$ to determine the specificity of the PCR reaction. The results were normalized based on the $\mathrm{C}_{\mathrm{T}}$ values obtained from the standard curve of the $26 \mathrm{~S}$ gene.

*Further details about the Electronic Supplementary Material (ESM) can be found at the end of the article. 


\section{Results}

The 200 EST were identified, but for this research 49 were selected, which had fragment lengths in the range of 200 to $800 \mathrm{bp}$. Sequences of these genes were compared to the GenBank database (http://blast.ncbi.nlm.nih.gov/) and showed similarities with reported genes expressed under abiotic and biotic stress.

Regarding abiotic stress, the sequences identified in this research were similar to those reported in wheat seedlings subjected to low temperatures (CV778623.1); to sequences expressed in wheat roots in response to treatments with aluminium (CJ838083.1); to sequences expressed in seedlings under low luminosity (etiolation) (AJ716624.1); to those expressed in seedlings subjected to a constant temperature of $22{ }^{\circ} \mathrm{C}$ (HX254763.1); to sequences expressed in heat-stressed flag leaves (CD453375.1, AJ602736.1); to another sequences of plants subjected to desiccation stress, temperature treatment, photoperiod, humidity and treatment with ABA (CJ544882.1); and to sequences expressed in developing seeds under heat stress (GD187500.1).

Regarding biotic stress, the identified genes were similar to those found in a subtractive library of leaves subjected to a Diuraphis noxia infestation in wheat plants (CA483752.1, CA483766.1); to genes in Fusarium-inoculated spikes (EB513624.1); to plant genes that were inoculated with the fungus Magnaporthe oryzae (CJ967255.1); to seedlings infected with Blumeria graminis f. sp. tritici (JZ124120.1); to plant genes that were infected with leaf rust in the seedling stage (BG906694.1); and to genes in seedlings subjected to yellow rust (GR303234.1, FE900131.1).

The expression profile of each gene analysed by RT-PCR showed differences between susceptible and resistant genotypes (Fig. 1, Fig. S1). Genotypes reported as resistant showed high expression levels compared to susceptible ones. Densitometry analysis shown that by the expression levels of the genes TaYr-1, TaYr-6, TaYr-7, TaYr-8, TaYr-21, TaYr-26, TaYr-37, TaYr-38, TaYr-39, TaYr-45, TaYr-48 and TaYr-49, resistant and susceptible genotypes could be separated. Genotype 143 showed high levels of gene expression, unlike genotype 16, which had lower levels of expression. The densitometry analysis grouped genes into induced, constitutive or repressed (Fig. 1). The criterion for classifying the expression type of each selected gene was based on the densitometric values obtained from the susceptible genotypes (mean \pm standard deviation): values above the upper limit (mean + one standard deviation) were considered induced genes; values below the lower limit (mean - one standard deviation) were considered repressed genes; and values between the upper and lower limit were considered genes with constitutive-like expression.

Genotypes 21 and 143 showed 30 and 29 induced genes, respectively, while line 16 did not induce any gene (Fig. S2). Several genotypes showed differences in their expression patterns, according to their degree of susceptibility or resistance to yellow rust and the different molecular mechanisms that operate in each of them. Genotypes 21 and 143 showed the highest levels of expression among all the materials analysed under yellow rust infection. Genotype 2 presented the highest number of repressed genes of all the genes analysed in this research. 


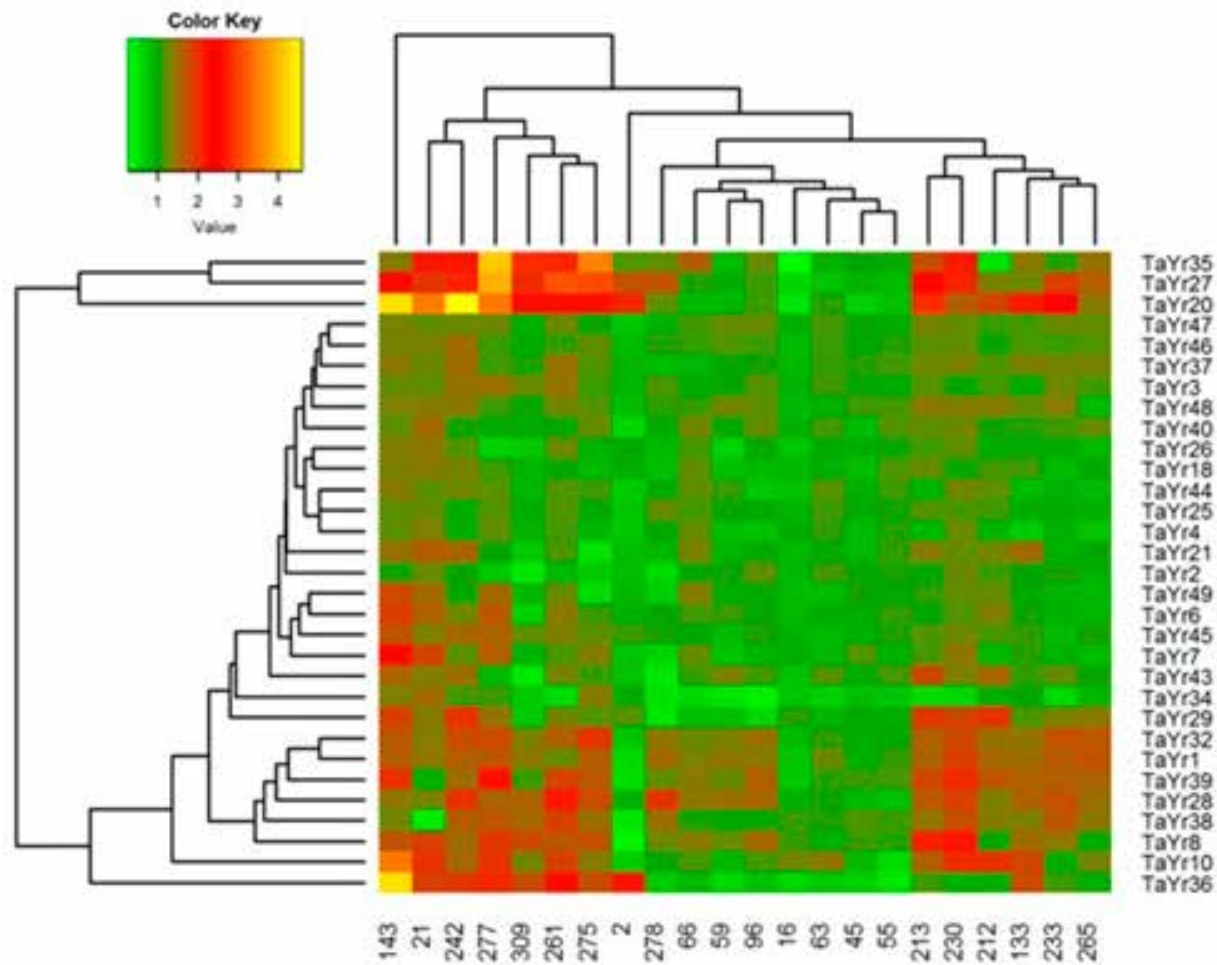

Figure 1. Heatmap showing the expression profile of the resistant and susceptible wheat lines studied. The colors red to yellow indicate induced genes, the green color indicates repressed genes, and the brown color indicates constitutive genes. The abscissa represents the advanced wheat lines and the ordinate the genes studied. The four corners show the highest level of expression of induced genes. The advanced lines 143, 21, 242, $277,309,261,275,213,230,212,133,233$ and 265 presented the highest expression levels and all of them were resistant to $P$. striiformis under field conditions (Table 1). None of the susceptible advanced lines shows a high expression like the previous ones. The genes TaYr35, TaYr27, TaYr20, TaYr29, TaYr32, TaYr1, TaYr39, TaYr28, TaYr38, TaYr8, TaYr10 and TaYr36 are candidates for inducing resistance to yellow rust. The upper and left side dendrograms show groups of genotypes and genes associated with resistance and susceptibility to rust

From the expression analysis by RT-PCR, some differentially expressed genes were selected only to validate the results by RT-qPCR. For this purpose, genotypes 16, 21 and 143 with low, intermediate and high expression level, respectively (Fig. 1), were chosen and TaYr-1, TaYr-8, TaYr-10, TaYr-32 and TaYr-49 genes were selected. The results of the RT-qPCR showed that the transcript accumulation of each gene was different between resistant and susceptible plants, but similar to RT-PCR results (Fig. 2). For all genes tested, genotype 16 showed the lowest levels of accumulated transcripts. However, in the case of the resistant genotypes, the TaYr-10 and TaYr-32 genes showed the highest transcript accumulation; in particular, the accumulation of transcripts of the TaYr-10 gene was 30 times greater than in the control (genotype 16), indicating a continuous accumulation 


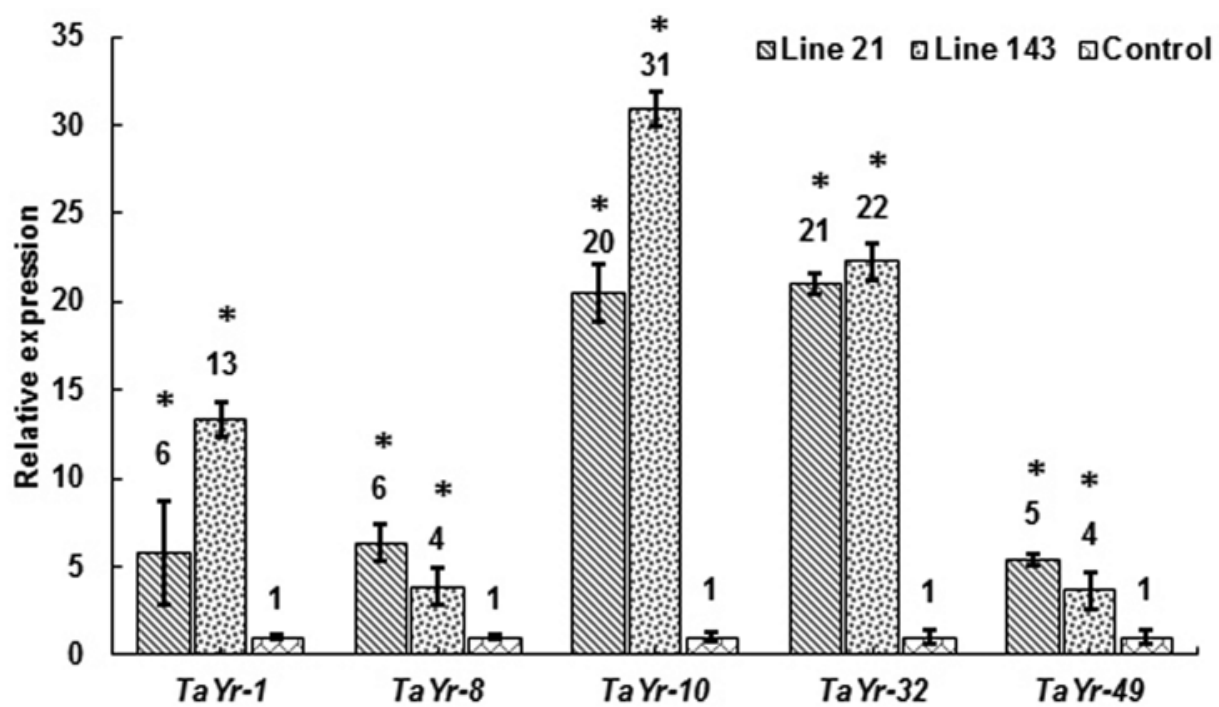

Figure 2. Relative expression levels of the TaYr-1, TaYr-8, TaYr-10, TaYr-32 and TaYr-49 genes in the real-time RT-qPCR of the advanced lines 21 (resistant), 143 (resistant) and 16 (susceptible), which was used as control. Mean $\pm \mathrm{SD}$; the asterisks indicate differences with a level of significance at $0.05 \% . \mathrm{N}=3$

of the transcript in response to yellow rust. On the other hand, the genes $T a Y r-1, T a Y r-8$ and $T a Y r-49$ had the lowest accumulation of transcripts in the resistant genotypes; however, their accumulation was significantly higher than in the control.

\section{Discussion}

The genes isolated at higher proportions had unknown functions (40\%), and other genes had functions related to the response to biotic stress (30\%), the response to abiotic stress $(22 \%)$ and growth (8\%). These results are similar to those reported by Li et al. (2015), who worked with isogenic lines of wheat and found that $39 \%$ of genes corresponded to genes with unknown functions, $25 \%$ related to photosynthesis and $14 \%$ related to cellular processes. These differentially expressed genes are, some of them, similar to those identified in this research because during infection there were transcribed genes related to biotic stress, although the specific roles they play are unknown. The binding genes reported by these authors are of the NBS-LRR type, ATP-binding type and $\mathrm{Ca}^{2+}$-binding type, which are related to oxidative burst; the roles of the transporter genes are in detoxification and transport of toxic substances. In this research a gene associated with binding activity was found, and this could be associated with detoxification or cell recognition. A greater proportion of genes corresponded to unknown functions and genes related to defence against pathogens; among the important genes that are reported by these authors are genes related to pathogenesis, genes related to abiotic stress and genes involved in reactive oxy- 
gen species (ROS). However most of the identities of the genes found in the yellow rust library were not identified.

The plant-pathogen interaction implies the continuous synthesis of defence genes, which recognize the pathogen through molecules derived from tissue damage such as pathogen-associated molecular patterns (PAMP) (Tang et al. 2015; Dmochowska-Boguta et al. 2015). The structure of a common receptor in plants includes the presence of Leucine Rich Repeat (LRR) proteins, which are typical of R-proteins; the expression of this gene (CA483766.1) indicates that V-26 has the capacity to perceive the pathogen and trigger the basal resistance mechanism continuously (Yang et al. 1998).

Li et al. (2015) mention that another mechanism involved in the resistance of wheat to yellow rust is the induction of senescence and photosynthesis genes; this is consistent with the results of the present work that identified the RuBisCO sequence (BG906694.1), which is a fundamental enzyme of photosynthesis; the induction of this gene could be related to a greater demand of energy to the multiple lesions in plants induced by the pathogens (Xingquan et al. 2010). Rehman et al. (2013) mention that rust affects photosynthesis, and the result is a low harvest of seeds; another possibility is a greater demand for the photoassimilates by the pathogen, and in this situation, the plant would have to compensate its production.

The accumulation of resistance-related transcripts in the early stages of infection is important for a timely response, and the use of RT-qPCR can establish minimal differences between genotypes evaluated. The results obtained by Huang et al. (2013) indicated that the greatest accumulation of transcripts for genes analysed by RT-qPCR was at 24 hours after inoculation, and then accumulation decreased after 120 hours. In another research that evaluated 7 candidate genes related to the resistance to yellow rust, an increase of transcription after 24 hours was observed; however, this response decreased over time (Xingquan et al. 2010). Durable expression of these genes could contribute to the resistance in adult plants, and in the case of this research, the subtracted genes of the V-26 line participated in prolonged resistance to yellow rust.

The TaYr-10 and TaYr-32 genes had higher relative expression than the genes analysed by Huang et al. (2013) and Xingquan et al. (2010); there was also 17-fold higher expression of these genes in resistant genotypes than in genotype 16 (susceptible to rust), while for the other analysed genes (TaYr-1, TaYr-8 and TaYr-49) the expression was 2-fold higher in resistant genotypes than in the susceptible ones. In the case of leaf rust, Dmochowska-Boguta et al. (2015) analysed genes expressed during the plant-pathogen interaction, and the RT-qPCR showed a higher relative accumulation of transcripts in the varieties with medium and high resistance; on the other hand, in the susceptible variety a smaller relative accumulation was observed. Results of this work showed that wheat varieties that do not accumulate the necessary transcripts to prevent the advance of the pathogen would be at a disadvantage to avoid damages.

The genes obtained from this research demonstrate their involvement in the response of the V-26 genotype to yellow rust; likewise, the results of the expression profiles indicated that advanced resistant lines presented an overexpression of the genes that could be related to resistance to yellow rust. 


\section{Acknowledgements}

The author thanks Consejo Nacional de Ciencia y Tecnología through the Instituto Tecnológico de Roque for the scholarship granted to J.L. Zárate-Castrejón for doctoral studies that included the period 2014-2017, and the project financed by Fondos Fiscales of Secretaría de Agricultura, Ganadería, Desarrollo Rural, Pesca y Alimentación-Instituto Nacional de Investigaciones Forestales, Agrícolas y Pecuarias, project No. 8422632063.

\section{References}

Ali, S., Gladieux, P., Leconte, M., Gautier, A., Justesen, A.F., Hovmøller, M.S., Enjalbert, J., de Vallavieille-Pope, C. 2014. Origin, migration routes and worldwide population genetic structure of the wheat yellow rust pathogen Puccinia striiformis f. sp. tritici. PLoS Pathog. 10:e1003903.

Bimboim, H., Doly, J. 1979. A rapid alkaline extraction procedure for screening recombinant plasmid DNA. Nucleic Acids Res. 7:1513-1523.

Dmochowska-Boguta, M., Alaba, S., Yanushevska, Y., Piechota, U., Lasota, E., Nadolska-Orczyk, A., Karlowski, W.M., Orczyk, W. 2015. Pathogen-regulated genes in wheat isogenic lines differing in resistance to brown rust Puccinia triticina. BMC Genomics 16(1):742.

Huang, X.L., Ma, J.B., Chen, X., Wang, X.J., Ding, K., Han, D.J., Qu, Z.P., Huang, L.L., Kang, Z.S. 2013. Genes involved in adult plant resistance to stripe rust in wheat cultivar Xingzi 9104. Physiol. Mol. Plant Pathol. 81:26-32.

Hussain, S., Ahmad, M., Farhatullah, M.I., Shah, S.J.A. 2014. Characterization of slow rusting resistance against Puccinia striiformis f. sp. tritici in candidate and released bread wheat cultivars of Pakistan. J. Plant Pathol. Microbiol. 5:223.

Jørgensen, L.N., Hovmøller, M.S., Hansen, J.G., Lassen, P., Clark, B., Bayles, R., Rodemann, B., Flat, K., Jahn, M., Goral, T., Czembor, J.J., Cheyron, P., Maumene, C., de Pope, C., Ban, G.R., Nielsen, C., Berg, G. 2014. IPM strategies and their dilemmas including an introduction to www. eurowheat. org. J. Integr. Agr. 13(2):265-281.

Lagudah, E.S. 2011. Molecular genetics of race non-specific rust resistance in wheat. Euphytica 179(1):81-91.

Li, X., Liu, T., Chen, W., Zhong, S., Zhang, H., Tang, Z., Chang, Z., Wang, L., Zhang, M., Li, L. 2015. Wheat WCBP1 encodes a putative copper-binding protein involved in stripe rust resistance and inhibition of leaf senescence. BMC Plant Biol. 15(1):239.

Logemann, J., Schell, J., Willmitzer, L. 1987. Improved method for the isolation of RNA from plant tissues. Anal. Biochem. 163:16-20.

Ma, J., Huang, X., Wang, X., Chen, X., Qu, Z., Huang, L., Kang, Z. 2009. Identification of expressed genes during compatible interaction between stripe rust (Puccinia striiformis) and wheat using a cDNA library. BMC Genomics 10(1):586.

Milus, E., Line, R., 1986. Number of genes controlling high-temperature, adult-plant resistance to stripe rust in wheat. Phytopathology 76:93-96.

Mishra, C., Kumar, S., Gupta, V., Tiwari, V., Sharma, I. 2015. Utilization of chlorophyll content index (CCI) to infer yellow rust severity in wheat (Triticum aestivum L.). J. Appl. Nat. Sci. 1:38-42.

Montero-Tavera, V., Escobedo-Landín, M.A., Acosta-Gallegos, J.A., Anaya-Lopez, J.L., Ruiz-Nieto, J.E. 2017. 26S: Novel reference gene from leaves and roots of common bean for biotic stress expression expression studies based on PCR. LEGUME RES 40(3):429-433.

Rehman, A.U., Sajjad, M., Khan, S., Ahmad, N. 2013. Prospects of wheat breeding for durable resistance against brown, yellow and black rust fungi. Int. J. Agric. Biol. 15(6):1209-1220.

Reiss, A., Jørgensen, L.N. 2017. Biological control of yellow rust of wheat (Puccinia striiformis) with Serenade ${ }^{\circledR}$ ASO (Bacillus subtilis strain QST713). Crop Prot. 93:1-8.

Rodríguez-García, M., Huerta-Espino, J., Villaseñor-Mir, H., Solís-Moya, E. 2009. Virulence of the wheat yellow rust in the main irrigated production areas of Mexico. Agric. Tec. en Mex. 35:179-187. 
Sambrook, J., Russell, D.W. 2001. Molecular cloning: a laboratory manual 3rd edition. Coldspring-Harbour Laboratory Press, UK.

Solís-Moya, E., Huerta-Espino, J., Villaseñor-Mir, H.E., Pérez-Herrera, P., Ramírez-Ramírez, A., Ledesma-Ramírez, L., de la Cruz-González, M. de L. 2014. Luminaria F2012, new bread wheat variety for restricted irrigation in El Bajío. Rev. Mex. De Cienc. Agric. 5:325-330.

Tang, C., Wang, X., Cheng, Y., Liu, M., Zhao, M., Wei, J., Kang, Z. 2015. New insights in the battle between wheat and Puccinia striiformis. FASE 2(2):101-114.

Xingquan, Z., Changyou, W., Ali, M., Hong, Z., Xinlun, L., Weiyan, L., Wanquan, J. 2010. Profiling gene expression patterns of stripe rust (Puccinia striiformis f. sp. tritici) resistance gene in new wheat germplasm. Pak. J. Bot. 42:4253-4266.

Yang, E., Zou, Y., Yang, W., Tang, Y., Zhonghu, H., Singh, R. 2011. Breeding adult plant resistance to stripe rust in spring bread wheat germplasm adapted to Sichuan Province of China. Proc. $8^{\text {th }}$ Wheat Conf, and BGRI 2010 Technical Workshop, 2010. St. Petersburg, Russia 47:S165-S168.

Yang, Q., Grimmig, B., Matern, U. 1998. Anthranilate N-hydroxycinnamoyl/benzoyltransferase gene from carnation: rapid elicitation of transcription and promoter analysis. Plant Mol. Biol. 38:1201-1214.

Yin, C., Chen, X., Wang, X., Han, Q., Kang, Z., Hulbert, S.H. 2009. Generation and analysis of expression sequence tags from haustoria of the wheat stripe rust fungus Puccinia striiformis f. sp. tritici. BMC Genomics 10:626.

\section{Electronic Supplementary Material (ESM)}

Electronic Supplementary Material (ESM) associated with this article can be found at the website of CRC at http://www.akademiai.com/content/120427/

Electronic Supplementary Table S1. Primers of differentially expressed genes in flag leaf from the suppressive subtractive library of the V-26 line resistant to yellow wheat rust

Electronic Supplementary Figure S1. Expression profiles of the subtracted genes from V-26 wheat line; the numbers at the top indicate the genotype number in the National Wheat Collection of INIFAP. The numbers in the left column indicate the selected genes

Electronic Supplementary Figure S2. Induced and repressed genes in each genotype. The values above zero indicate the overexpression of the genes; the negative bars show the repressed genes; grey bars show the maximun and minum expression values. The ordinates axis represents the expression levels of the genes tested. The order of the genes from left to right is TaYr-1, TaYr-2, TaYr-3, TaYr-4, TaYr-5, TaYr-6, TaYr-7, TaYr-8, TaYr-10, TaYr-18, TaYr-20, TaYr-20, TaYr-20, TaYr-20, TaYr-25, TaYr-26, TaYr-26, TaYr-27, TaYr-28, TaYr-29, TaYr-38, TaYr-39, TaYr-40, TaYr-43, TaYr-44, TaYr-45, TaYr-46, TaYr-47, TaYr-48 and TaYr-49 